\title{
1 Religiously foreign and nationally undesirable
}

"Truly! Neither Jews nor Jesuits, with all their Cunning combined, could accomplish as much Evil as the Mormons if they gained a real Foothold in the Country." The quotation is taken from an impassioned reader's contribution to the Norwegian newspaper Morgenbladet in 1852, and illustrates this book's theme - namely how religious minorities and groups originating beyond Scandinavia were portrayed as enemies of society throughout the region from the $1790 \mathrm{~s}$ until after the mid-1900s. This will be explored by examining precisely how, at different times, Jews, Mormons and Jesuits were viewed as a moral, political and national threat to Scandinavian society and state. In different periods, each group was regarded as foreign, dangerous and undesirable. Key questions are who gave voice to the notion that these minorities were socially harmful, what constituted the danger, and the extent to which ideas about social perils had an impact on state religious policy. An overarching question is what all this has to say about the definition of national self-identity in Scandinavia.

A common feature for all Scandinavian countries was the dominant position of the Evangelical Lutheran Church until long into the 20th century. It was the state church in each country and had been endowed with a legal religious monopoly up until the Dissenter Act in Norway in 1845, the Constitution of 1849 in Denmark, and the Dissenter Act of 1860 in Sweden. Even though the hegemonic position of the established churches came to be contested - especially by Christian dissenters who worked to promote the legality of religious pluralism - religious practice throughout Scandinavia was more or less uniform under the stewardship of each country's state-appointed clergy during the period covered by this book.

In the Swedish Constitution of 1772, religious unity was explicitly regarded as the "strongest foundation for a legal, harmonious and lasting government." It therefore resolved that the king of the country, officials and subjects would be

1 Morgenbladet no. 324, 11 November 1852. The correspondent signed off as "T.M.L.": "Sandelig! Hverken Jøderne eller Jesuitterne med al deres Snuhed tilsammenlagt ville kunne udrette saa meget Ondt som Mormonerne, hvis de skulle faa rigtig Fodfeste her i Landet.”

2 Wikisource: Regerings-Form 1772, 21 August 1772, §1. [https://sv.wikisource.org/wiki/Regeringsform_1772, accessed 24 October 2016]. Authors translation of "kraftigaste grundvalen til et lofligit, samdrägtigt och varaktigt Regimente." See also Per-Olov Ahrén, "Religionsfriheten och RF § 16,” Svensk Tidskrift (1956): 453ff. Ingun Montgomery, “Den svenska religionspolitiken,” in Reformationens konsolidering i de nordiska länderna 1540-1610, ed. Ingmar Brohed (Oslo: Universitetsforlaget, 1990), 127 ff. Patrik Winton, "Enighetens befrämjande och fäderneslandets förovran: religion och politik under frihetstiden,” Sjuttonhundratal (2006/2007).

2 OpenAccess. (C) 2021 Frode Ulvund, published by De Gruyter. (cc) BY-NC-ND This work is licensed under the Creative Commons Attribution-NonCommercial-NoDerivatives 4.0 License.

https://doi.org/10.1515/9783110657760-003 
faithful to the religion of the state church, just as every Swedish Constitution since 1634 had done. While the Constitution of 1809 did indeed declare religious freedom, at the same time it made it illegal to withdraw from the state church. ${ }^{3}$ As a consequence, only immigrants with a background in a religion other than that of the Evangelical Lutheran state were permitted to practise a divergent faith. In addition came the Jewish minority, who had been allowed to settle in certain Swedish cities in the 1780s. In practice, then, Swedish subjects continued to be subject to a strict religious regime without appreciable liberty until the Religious Freedom Act of 1951.

Particularly from the 1850 s onwards, demands for genuine freedom of religion were formulated in the Swedish public sphere both as an expression of general political liberalism, and by emergent revival movements that found the legal framework detrimental to their activities. ${ }^{4}$ A prominent and controversial lawsuit pending in the Swedish judicial system in the same decade stirred international attention and growing debate on Swedish religious policy. ${ }^{5}$ Six Swedish women were sentenced to banishment for having converted to Catholicism, and in the end were set on a vessel out of the country in the summer of 1858. On his own initiative, King Oscar I (1799-1859) raised the issue of religious freedom at the highest level when he made mention of the case during his royal address of 1856. The king, French-born and himself originally Catholic, was also married to the Catholic Queen Josephine.

In Sweden, a first redoubt fell when the Conventicle Ordinance (the prohibition on congregating - konventikkelplakaten) was repealed in 1858. Two years later, a Dissenter Act granted Swedish citizens - subsequent to repeated imposition of admonitions and reprimands, and upon application to the king - permission to leave the state church and join foreign Christian faiths. ${ }^{6}$ This law must also be viewed in relation to an amendment to the Responsibility Act (Ansvars-

3 Oscar Hippel, "Religionsfriheten och den sextonde paragrafen regeringsformen: Bidrag til frågans bedömande fram til dissentarlagen år 1860,” in Teologiska studier: Tillägnade Erik Save på 65-årsdagen den 10 juni 1922 av kolleger og lärjungar (Uppsala: Almqvist och Wiksells Boktryckeri AB, 1922), $247 \mathrm{ff}$. Article 16 of the 1809 Constitution: "The king should ... compel or cause to compel no one's conscience, but protect each one in the free exercise of his religion, so far as he does not disturb the tranquility or general indignation of society." Quoted here from Ahrén, "Religionsfriheten och RF §16," 454.

4 Ahrén, "Religionsfriheten och RF § 16," 454.

5 Erik Sidenwall, “The Elusiveness of Protestantism: The Last Expatriations for 'Apostasy' from the Church of Sweden (1858) in a European Perspective," Journal of Religious History, vol. 31, no. 3 (September 2007); Dahlman, P., Kyrka och stat i 1860 års svenska religionslagstiftning (Skelleftea: Artos, 2009), 33f.

6 Dissenter Act of 1860, §1. Quoted from Dahlman, P., Kyrka och stat, 449. 
förordningen) adopted the same year. It still had penal provisions for proselytising activity and the spread of "heretical teachings," but decriminalised apostasy from the "true faith." The act referred to defectors as "apostates" (avfälling), which in Swedish provided associations to divisive individuals and subversive undertakings. The Dissenter Act of 1873 did away with the pejorative characterisation of those who withdrew from the state church and opened up for the secession of anyone wishing to join another Christian denomination without having to go through a process of admonition led by the priest.

Debates over the terms for withdrawal from the Swedish state church took place regularly over subsequent decades. However, religious freedom and the unconditional right to leave the state church were only granted to all Swedish citizens, irrespective of religious faith, in $1951 .^{8}$ This was the result of a political process that began with the appointment in 1943 of a Committee on the Dissenter Act that was commissioned to recalibrate religion legislation in closer accordance with the prevailing principles of religious freedom. ${ }^{9}$ Sweden's ratification of the European Convention on Human Rights, adopted by the Council of Europe in 1950 , contributed to bringing the process to a close. ${ }^{10}$ It now became formally lawful for members of the Swedish state church to disengage from it without having to register with another Christian congregation. Although the supervision of such membership never occurred after 1860, this meant that it was only now formally permissible for former members of the state church to adhere to an atheistic life stance or a non-Christian religion.

In Denmark, the situation in the years leading up to 1849 was much the same as its Scandinavian neighbours. Prior to the 1840s its legislation had much in common with Norway, which until 1814 was subject to Danish sovereignty. From the 18th century there were a number of precepts regulating the exercise of religion in Denmark and Norway. Christian V's Danish (1683) and Norwegian (1687) Codes held that the only permissible doctrine in the two countries was that of the Evangelical Lutherans, and featured, for example, the death penalty for "Monks, Jesuits and similar Individuals of the Papist Clergy" encoun-

7 Statens offentliga utredningar [State Public Report] (SOU, 1927-13), Betänkande med förslag angående vidgad rätt till utträde ur Svenska kyrkan jämte därmed sammanhängande frågor, 47; Statens offentlige utredningar (SOU, 1964-13), Religionsfrihet, 17.

8 Sveriges Riksdag [Swedish Parliament], Religionsfrihetslag (1951: 680).

9 Statens offentliga utredningar [State Public Report] (SOU, 1949-20), Dissenterlagskomittén betänkande med förslag till religionsfrihetslag m.m., 1.

10 Victoria Enkvist, Religionsfrihetens rättsliga ramar (Uppsala: Iustus förlag, 2013), 71. 
tered within the king's realms. ${ }^{11}$ The Conventicle Ordinance (Konventikkelforordningen) of 1741 regulated the right to congregate - essentially for Christians within the state church - in a not dissimilar fashion to that of Sweden. The ordinance did not prohibit religious gatherings - on the contrary, it regarded them as both edifying and useful - but they could only occur under the supervision of the local priest. Private devotionals were lawful as long as no outsiders were invited in. Section 8 of the ordinance also granted a limited right of assembly to individuals who were "sincerely seeking God" under certain conditions, first and foremost that the gathering was small and that it lasted only briefly.

The purpose of the ordinance was, of course, to exercise religious control and to maintain the religious unity of the dual monarchy. As arbiter of the state's norms, the church stood at the nucleus, having at its disposition a rostrum and an apparatus through which the power and authority of the state was sanctioned. A monopoly on confession secured its grip on this flow of information.

By 1745 , the authorities saw it necessary to clarify the understanding of religious freedom since "in sundry places in Denmark and Norway, quite a number of the King's native subjects have been led not merely astray, but also towards the corruptions of Separatism, by Adherents and Emissaries of Sects entering the Country here from abroad." ${ }^{12}$ The rescript regulated the activities of foreign religious sects. It provided for the right of residence, but under stringent restrictions and with banishment as possible punishment in case of transgression. Foreign sects without royal permission for the "free Practice of Religion in certain Places in the Country" were to be "wholly and utterly forbidden" and placed

11 Christian V's Norwegian Code (1687), 2-1-1. "On Religion”: The sole legal religion in the King's Realms is that in accordance with the Holy Scripture, the Confessions of the Apostles, the First Council of Nicaea and the Athanasian Creed, the 1530 Augsburg Confession and Luther's small Catechism. Original: "Den Religion skal i Kongens Riger og Lande alleene tilstædis, som overeens kommer med den Hellige Bibelske Skrift, det Apostoliske, Nicæniske og Athanasii Symbolis, og den Uforandrede Aar et tusind fem hundrede og tredive overgiven Augsburgiske Bekiendelse, og Lutheri liden Cathechismo;" 6-1-3: "Monks, Jesuits and other Papistical clerics found in the King's Realms are to be sentenced to death." Original: "Munke, Jesuviter og dislige Papistiske Geistlige Personer maa under deris Livs Fortabelse ikke her i Kongens Riger og Lande lade sig finde, eller opholde.” (Quoted here from http://www.hf.uio.no/iakh/tjenester/kunn skap/samlinger/tingbok/kilder/chr5web/chr5_02_01.html, accessed 10 August 2017.) Clause 2-1-1 has still not been formally removed from Norwegian law, but repealed in practice as a consequence of the Constitution having higher legal status than civil legislation (principle of Lex Posterior).

12 Edict (Rescript) 5 March 1745. Here from Fredrik August Wessel-Berg, Kongelige Rescripter, Resolutioner, Collegial-Breve for Norge i Tidsrummet 1660-1815. Første bind. 1660-1746 (Christiania: J.W. Cappelen, 1841), $916 \mathrm{ff}$. 
on the first ship out of the country. ${ }^{13}$ Neither was it lawful to remain in the kingdom for those individuals who "will not abide in all Matters [...] according to the Law of the King [...]"14

In addition, the rescript allowed for a certain degree of religious freedom, and those who, for reasons of conscience, divorced themselves from the official doctrine would be granted the opportunity to resolve their understanding of religion "pending further notice." If they arrived at the conclusion that they required further freedom, they would be obliged to seek the approval of the king. ${ }^{15}$ In any case, it was established that those who were to be "tolerated for the present time" should "bear the Burden with their fellow Citizens" in all matters and otherwise abide by the King's precepts regarding marriage, burial and "all other discernible Custom."16 In addition, the church ritual and stipulations thereof came with further clarifications concerning the religious monopoly.

In Denmark - as in Sweden - a Jewish minority represented a contrast to the hegemonic Evangelical Lutheran church. It had done so since the 1600s, but its presence was carefully regulated, as it had been almost everywhere in Europe where Jews were tolerated.

A breach in the religious ramparts occurred only when Denmark acquired a new Constitution in 1849, the year after the absolute monarchy was in practice abolished. Although the state church was granted privileges and declared a "National Church," the Constitution proclaimed religious freedom for all without restriction except in cases where the practice of religion led to public unrest or challenged established custom. ${ }^{17}$ This brought Denmark out in front in Scandinavia when it came to endorsing a notion of fundamental religious freedom. Yet even though the Constitution unequivocally codified religious freedom, we will see later that in the initial period there were some hazy interpretations as to quite how broadly the reality of religious freedom ought to be understood.

13 Edict (Rescript) 5 March 1745, §1.

14 Edict (Rescript) 5 March 1745, § 3.

15 Edict (Rescript) 5 March 1745, § 4.

16 Edict (Rescript) 5 March 1745, §5.

17 Jens Rasmussen, Religionstolerance og religionsfrihed: Forudsætninger og Grundloven i 1849 (Odense: Syddansk Universitetsforlag, 2009), 237. The 1849 Constitution of the Kingdom of Denmark: "§ 81. Citizens hold the Right to unite in Society to worship God in the Manner that is consistent with their Beliefs, provided, however, that nothing is taught or undertaken that is contrary to Morality or public Order. $\S 84$. No one may be deprived of the full enjoyment of civil and political rights by Reason of his Creed, or evade the Fulfillment of any ordinary civil Duty." (Quoted and translated from http://danmarkshistorien.dk/leksikon-og-kilder/vis/materiale/dan marks-riges-grundlov-af-5-juni-1849-junigrundloven/\#indhold7, accessed 12 October 2018). 
In this book, Norway is given special attention. Until 1814, the kingdom was subordinated as a territory within the absolutist and multinational state of the Danish king. A national revolt erupted when Norway was ceded to the Swedish king in January 1814, and a constitutional assembly drafted and adopted the 17th of May Constitution at Eidsvoll, north of Oslo, that same spring. After a brief period of independence under a Norwegian king, a short war with Sweden ended in union later that year. With minor adaptations, Norway held on to its Constitution, restoring Norway as an independent state in a union with Sweden under a joint king. Unless in violation of the Constitution, legislation from the absolutist period under the Danish king was kept as well, including religious regulations.

Norwegian religious policy during the union with Denmark was strict and indoctrinating. Obtaining independence and a constitution did not change that; quite the contrary. The Constitution of 1814 included a ban on Jews (repealed in 1851), monastic orders (repealed in 1898) and Jesuits (repealed in 1956). Mormons were also declared non-Christian in 1853 by the Supreme Court and denied the status of a lawful faith until freedom of religion was codified in the Constitution in 1964. The constitutional ban on certain religious groups not only restricted the parliament's ability to change religious laws as constitutional amendments required two-thirds majorities within parliament - but was also a vigorous token of exclusion from the nation. These bans and the enforcement of them - especially when it came to Jews - gave Norway an international reputation in the first half of the 19th century as brutal with regard to religious laws. ${ }^{18}$

There was no full, codified freedom of religion in Norway until 1964, and until the beginning of the 20th century, it was by no means a reality. At the Eidsvoll Constitutional Assembly in the spring of 1814, there was agreement on complete religious freedom for all Christians, but for reasons unknown it fell away as the Constitution was being ratified. It was only with the repeal of the Conventicle Ordinance in 1842 and the adoption of the Dissenter Act in 1845 (permission to form Christian religious communities) that an allowance was made for the exercise of religion beyond the confines of the official religion of the state, which eventually came to be known as the state church - but this was only for Christians. Although in the wake of the new Penal Code of 1902 there were no longer penal provisions that provided the legal authority to intervene against unlawful religious practice, in a formal sense it was not until the constitutional amendment of 1964 that everyone - Christians and non-Christians alike - was afforded

18 Frode Ulvund, Fridomens grenser 1814-1851: Handhevinga av den norske "jødeparagrafen" (Oslo: Scandinavian Academic Press, 2014), 14, 196. 
the equal right to the free exercise of religion. ${ }^{19}$ It was only then that the religious regimentation enshrined in Christian V's Norwegian Code of 1687 ceased to have any formal validity. Freedom of religion was later actively regulated by the Faith Communities Act of 1969.

However, the Constitution did not codify a boundless religious freedom. Both in 1974 and in 1980, the Supreme Court ruled that “the Constitution's provision on the right to the free exercise of religion has not been intended to warrant an unrestricted religious freedom that would grant citizens the right to refuse to fulfil a social obligation." ${ }^{20}$ These cases concerned individuals belonging to the Jehovah's Witnesses who refused to perform compulsory civilian national service as a substitute for military service, and demonstrated that the right to the exercise of religion was still dependent on compliance with the laws of the land.

The Norwegian state's religious policy in the period following 1814 can be divided into phases with their own distinctive features. ${ }^{21}$ A first phase, up until 1845, was characterised by strict religious regimentation. Religious communities beyond the Evangelical Lutheran state church were tolerated only to a very minor degree. After 1845, Christian religious communities were not placed on an equal footing with the state church, but tolerated and therefore permitted with restrictions. From the second half of the 19th century, religious communities that were not subject to the Dissenter Act were also increasingly tolerated - in the sense that the authorities more often than not refrained from intervening in illegal religious practices.

After the Penal Code entered into force in 1905, intervention against unauthorised religious practices could no longer be grounded in any legal authority, thus ushering in a de facto religious freedom. This led to great dissatisfaction among many in political and ecclesiastical circles, and soon provoked attempts to enact special legislation on religion to protect the state church and its doc-

19 Indeed, Norway ratified the European Convention on Human Rights in 1951, which established the free practice of religion, with no other exceptions besides the continued exclusion of Jesuits (see Ulrik Sverdrup-Thygeson, Grunnlovens forbud mot jesuitter og munkeordener: Religionsfrihet og grunnlovskonservatisme 1814-1956 (MA thesis, University of Oslo, 2009), 90 f.), but this was not incorporated into Norwegian law until 1999.

20 Norsk Retstidende, no. 44 (1974): 688 and Norsk Retstidende, no. 1 (1980): 537 ff. In the latter case, the first judge to cast his legal opinion referred to the wording of restrictions on religious freedom from 1974.

21 See Frode Ulvund, “'Til vern og fremme for religionen': Religion, politikk og rett etter 1814,” in Mellom gammelt og nytt: Kristendom i Norge på 1800- og 1900-tallet, ed. Knut Dørum and Helje S. Sødal (Bergen: Fagbokforlaget, 2016). 
trine. Although this never led anywhere, there were examples of the application of other laws and instruments to prevent undesirable religious influence. The denial of visas for Mormons in the post-World War I era is one such example; another is the attempt to refuse foreign religious communities a license to purchase property.

Religious communities outside the state church never constituted large groups in any of the Scandinavian societies during the period addressed in this book. Though all the countries were greatly influenced by lay Christian movements, most of these remained within the established church. At the beginning of the 1970s, 95 per cent of the Swedish population were still members of the state church..$^{22}$ The same was true of Denmark, where over 90 per cent of the population were members of the Danish national church until the latter half of the $1980 \mathrm{s.}^{23}$ In Norway, only two to three per cent of the population stood apart until after World War II; as late as 1970, 94 per cent of the population were members of the state church. ${ }^{24}$ Evangelical Lutheranism, within the confines of state church systems, thus held an almost ubiquitous grip on the religious life of the Scandinavian people throughout the period.

In 1875 , a quarter of a century after the prohibition on Jews was lifted, there were still only 25 Jews registered in Norway. By 1910 the figure had surpassed a thousand, but as late as the 1930s there were less than 1500 Jews in the country. ${ }^{25}$ According to the 1865 census, Mormons were the largest group outside the state church, with just over a thousand members. ${ }^{26}$ Their growth stagnated, however, and between 1875 and 1930 the number remained stable at around $500 .{ }^{27}$ As Catholics, Jesuits did not form their own religious community, and

22 Svenska kyrkans medlemsutveckling år 1972-2015. Svenska kyrkan (https://www.svenska kyrkan.se/default.aspx?id=1470789, accessed 11 October 2018).

23 Danmarks statistik [Statistics Denmark], 65 år $i$ tal. Danmark siden 2. verdenskrig (København, 2014), 21; Danmarks statistik, Dansk kultur- og mediestatistik 1980-1992 (København, 1993), table 14.4, 183. Among Danish citizens, the proportion that were members of the established church first dropped below $90 \%$ during the 1990 s.

24 In 1960 the figure was 96\%. Statistisk sentralbyrå [Statistics Norway], Folketelling 1960. Hefte VIII. Tabell 1. Personer utenfor statskirken etter trossamfunn. Bygder og byer fylkesvis; Statistisk sentralbyrå (1974). NOS A 679. Folke- og boligtelling 1970. Hefte I (Oslo, 1974), 73.

25 Det Statistiske Centralbyrå [Statistics Norway], NOS VII. 192. Folketellingen i Norge 1930: Trossamfund (Oslo: Aschehoug, 1932), Tabell 1. Folkemengden i Norge 1875-1930 fordelt efter trossamfund.

26 Det Statistiske Centralbyrå [Statistics Norway]. Statistisk aarbog for Kongeriget Norge. Første Aargang. 1880 (Kristiania, 1881), tabell 9:17.

27 Det Statistiske Centralbyrå [Statistics Norway], NOS VII. 192. Folketellingen i Norge 1930: Trossamfund (Oslo: Aschehoug, 1932), Tabell 1. Folkemengden i Norge 1875-1930 fordelt efter trossamfund. 
were moreover banned until 1956. Nor did the Roman Catholic Church collectively constitute a major group. It experienced gradual growth from the time it was permitted in Norway in 1843, but in 1930 it still had fewer than three thousand members from a population approaching three million. ${ }^{28}$ In 1920 , when more than 99 per cent of Swedes were members of the state church, the most significant groups outside it were Baptists $(7,265)$, the Jewish community $(6,469)$, Methodists $(5,452)$ and Catholics $(3,425)$. Other faith communities all had fewer than three hundred members. ${ }^{29}$ In Denmark in the same period, the Catholic Church was clearly the largest among the two per cent who stood apart from the state church $(22,137)$. Behind them came those of no faith at all $(12,744)$, Baptists $(6,989)$, the Jewish community $(5,947)$, and Methodists $(4,858) .{ }^{30}$

Although religious pluralism must be said to have constituted a marginal feature in Scandinavia due to such complete domination by the established churches, certain religious minorities nevertheless came under the spotlight, branded as a menace to society and viewed as an undesirable problem. This was the case in Sweden and Norway for almost the entire period until full religious freedom was introduced in the 1950s and 1960s, and in Denmark especially until the end of the 19th century. Some religious groups were portrayed as dangerous by key individual authorities within the church, in parts of the state apparatus, and by a variety of other actors in public debate. In that "false" religions and sects stirred religious confusion, and led apostates away from the state churches and towards eternal spiritual damnation, they were in part described as a religious threat. But as Christian-liberal ideas gained a foothold in the 19th century, the tool of religious coercion became problematic and controversial.

At the same time, religious communities outside the state churches were in many cases portrayed as politically dangerous. This was justified by allegations against their lack of loyalty to the state and its laws, their aspirations towards theocracy, and the charge that some religious communities represented a morality that was corrosive to state and society. A number of religions were seen as pretexts for political programs with agendas that, both politically and morally, were of a disruptive nature. Many leading figures in the clergy and religious policy thus depicted them as dangerous societal foes. It was far more credible to oppose religious deviation from the state church as harmful to political and social mores

28 Det Statistiske Centralbyrå [Statistics Norway], NOS VII. 192. Folketellingen i Norge 1930: Trossamfund (Oslo: Aschehoug, 1932), Tabell 1. Folkemengden i Norge 1875-1930 fordelt efter trossamfund.

29 SOU 1927-13, 63.

30 SOU 1927-13, 426. 
than as a spiritual threat. In Denmark, which established freedom of religion in the Constitution as early as 1849 , such notions were less prominent from the second half of the 19th century and religious groups were therefore construed less as a political or national peril, although Mormons in particular were also regarded as a problem there until the first two decades of the 20th century.

During this period, a number of different religious groups with origins beyond the borders of Scandinavia were perceived as representing a political challenge. In Norway, Quakers quickly came into conflict with the church and the government after the Napoleonic Wars, when the first converts returned from English captivity. This triggered both political and legal investigations into their religious practices. ${ }^{31}$ Before the Norwegian Dissenter Act was passed in 1845, certain Quakers were granted individual permits to practise their religion, albeit within a very strict framework. They were nevertheless still distrusted and disliked, and seen by some as representatives of "wild, unlawful Republicanism or even Anarchy," as the pastor of Skjold parish in western Norway referred to them in $1827 .^{32}$ This was mainly due to their pronounced pacifism and unwillingness to take oaths, and within the clerical order probably also to their outspokenness on matters of theology.

In northern Norway, the spread of Laestadianism in the mid-1800s challenged not only the state church, but also national unity and control. Laestadianism had strong ethnic associations and was closely linked to the Sami indigenous population and Kven immigrants from Finland. Hostile images were formed not only portraying Laestadians as religiously problematic, but also linking them to a security and ethnic threat to the nation. ${ }^{33}$ It was within this context that Laestadianism was understood to be instrumental to a proactive Finnish nationalism in the northern regions, and therefore perceived as a "Finnish danger."34

In this book, I will discuss three other foreign religious groups or minorities: Jews, Mormons, and Jesuits. For periods in the era from around 1790 until about the middle of the 20th century, all were regarded as a particular danger by po-

31 Frode Ulvund, “'Grundlovens Taushed': Høgsterett og religionsfridomen mellom Grunnlova og dissentarlova,” Teologisk Tidsskrift, no. 4 (2014).

32 Letter from pastor Thomas Swensen in Skjold to senior rector Paul Knutsen in Jelsa, quoted here from Andreas Seierstad, Kyrkjeleg reformarbeid i Norig i nittande hundreaaret (Bergen, 1923), 340.

33 Rolf Inge Larsen, Religion og fiendebilder - læstadianismen, statskirken og kvenene 18701940 (PhD diss., University of Tromsø, 2012).

34 Einar Niemi and Knut Einar Eriksen, Den finske fare: Sikkerhetsproblemer og minoritetspolitikk i nord 1860-1940 (Oslo: Universitetsforlaget, 1981), 52 f. 
litical and clerical-theological authorities and institutions - and, for that matter, by wider society. What they also had in common was that they came into conflict with the Scandinavian authorities in different ways. This was especially true in Norway, partly due to constitutional prohibitions. In Sweden, and in Denmark too until the beginning of the 20th century, confrontations with and political and legal persecution of adherents of other creeds occurred from time to time, including banishments and restrictions on entry.

It is crucial to set out who perceived these groups as dangerous, and why this happened. As for the consequences of these notions for the minorities themselves, this book will confine itself to a discussion of the various authorities' overarching religious policies. There will be a focus on how hegemonic images of religious "others" were constructed and gained political significance in social debate, and not on a discussion of the validity of these notions or a demonstration of attempts to create counter-representations. The ways in which these minorities saw themselves, and the everyday experiences or perceptions they gained by being considered dangerous, will not, therefore, be a major theme here.

Notions of the political and societal hazards posed by these religious minorities had many parallels, and objections to one minority could just as well be used against another. The quote from the newspaper Morgenbladet that opens this chapter illustrates an assertion of danger while simultaneously linking these groups together. The idea that religious minorities such as Jews, Mormons and Jesuits constituted a real threat towards society was founded on a master narrative in which religious "Others" were represented as foreign and cosmopolitan powers. Dutch historian Krijn Thijs defines such a narrative as "an ideal typical 'narrative frame' whose pattern is repeated, reproduced and confirmed by highly diverse historical practices." ${ }^{35}$ This was very much the case for the religious groups discussed in this book.

In many ways, these notions also sprang from the same well, and it will be essential to show the extent to which there was continuity in the descriptions of danger when the various minorities were being mentioned. One example is the notion that Jews, Jesuits, and Mormons all formed a "state within the state" and therefore threatened the sovereignty of the political powers.

These representations - like the minorities themselves - were distinctly transnational. Descriptions of religious "others" were strongly influenced by

35 Krijn Thijs, "The Metaphor of the Master: 'Narrative Hierachy' in National Historical Cultures of Europe," in The Contested Nation: Ethnicity, Class, Religion and Gender in National Histories, ed. Stefan Berger and Chris Lorenz Basingstroke: (Palgrave MacMillan, 2008), 68. 
conceptions and circumstances beyond the individual countries. Assertions of political peril circulated within and between various intellectual and public spheres. ${ }^{36}$ Being imported and applied, they yielded little to national frontiers. As such, these ideas typically appear to be relatively stable in form, while at the same time the ways in which they were employed can be characterised both by dynamism and a great capacity to be transferred into actualised "threats."

It is impossible to understand how ideas of religious pluralism as a political danger could typify the governments and societies of Scandinavia during this era without being familiar with the European history of these conceptions from the period prior. Conceptions about these groups must, therefore, be placed into a historical context, not least by tracing their European and Scandinavian roots in the period leading up to the end of the 18th century. Likewise, being acquainted with the history of toleration and the concept of it in the preceding period is imperative to understanding the legitimacy of exclusion, especially as it was expressed by the founding fathers of the Norwegian Constitution at Eidsvoll, and in the Swedish Riksdag. A discussion of the perception of religious aberration as a social peril in Scandinavia from the late 18th century onwards is therefore inconceivable if one does not illuminate the international and historical contexts of these religious policies and notions. Accordingly, representations that were active in Scandinavia ought also to be seen against their international backdrops. This also implies demonstrating that religious freedom in the West at the beginning of the 19th century was, in reality, an abstraction, and that dissenting religious practices were not ordinarily enshrined in rights, but in reluctant permissions. There was also a common belief among intellectual elites and authorities in the West that political threats would more easily justify an absence of toleration than religious objections could.

In the first part of the 19th century, Jews were generally disliked and mistrusted in all the Scandinavian countries. Yet this nevertheless resulted in in religious policy taking divergent courses: segregation in Sweden, assimilation in Denmark, and exclusion in Norway. The view of Jews as a political danger - regardless of the choice of direction - was in large part a shared notion. In this book the Norwegian prohibition on Jews from 1814 to 1851, in particular, will be illuminated in its continental and Scandinavian context. The ban must be understood in light of claims that because they were morally corrupt, politically

36 See Pierre-Yves Saunier, Transnational History (Basingstoke: Palgrave MacMillan, 2013) for a theoretical discussion of transnationalism. This book is inspired by his usage of concepts such as circulation, circuit and connectors to describe and explain how ideas, notions and attitudes move across national borders. 
disloyal, and hostile towards any non-Jewish nation, Jews were unsuitable citizens of Christian states. Such representations were central prior to 1814, during what was called the Jewish emancipation, and in the years that followed, but were less pronounced in public remarks on the Jews, especially among government officials, from the 1840 s onwards.

The first missionaries from the Mormon Church in Utah (The Church of Jesus Christ of Latter-day Saints) arrived in Denmark and Sweden in 1850, and in Norway in 1851 - the same year that the Norwegian ban on Jews was lifted. They rapidly came into conflict with the church and government, and unleashed great passion among the general public. The Norwegian Supreme Court declared them non-Christians in 1853, and in the same year the Norwegian government denied them the protections of the Dissenter Act for reasons both political and religious. This occurred in contrast to Jews, whose religious practice was regulated by the Dissenter Act in 1851, even though they were not Christians.

Mormons were portrayed as communists and, in Norway, as kindred Thranites (from the workers movement led by Marcus Thrane around 1850), in addition to being referred to as the Mohammedans of the West, said to harbour ambitions towards theocracy. From the 1860s, Mormons were for the greater part tacitly tolerated by Scandinavian authorities for fear that legal persecution would make martyrs of them. Yet they were long referred to as "enemies of the social order," and the doctrine of polygamy in particular inspired lengthy accusations that they were engaged in the white slave trade of Scandinavian girls. In the interwar period, attempts were made to keep them out of Scandinavia by denying them visas. As late as 1955 their approval as Christians was rejected in Norway, thereby denying them the protections of the Dissenter Act. In 1896, Japanese citizens were granted free religious practice in Norway by means of a treaty agreement. This drew attention to the fact that there was still an absence of universal religious freedom for non-Christians in Norway in the late $1800 \mathrm{~s}^{37}$ At the same time - along with the treatment of the Jews in 1851 - this demonstrated that the prohibition on non-Christian religious practice was nonetheless not grounded in principle, and that the staunch rejection of Mormons was not, therefore, mere happenstance, but highly intentional.

37 Stortingsforhandlinger. Del 2b. Sth. Prp. No 107 (1896). [Records of the Proceedings of the Norwegian Parliament (Storting). Part 2b. Proposition to ratify The Treaty of Amity, Trade and Shipping ("Venskabs-, Handels- og Søfartstraktat") between Norway/Sweden and Japan (1896)], Article I. The treaty did not specify to which religion(s) this applied. In this period, Shintoism was the state religion and, along with Buddhism, dominated among Japanese citizens, but the Japanese Constitution of 1868 had codified free religious practice for all its citizens. 
The perception of Mormons in Scandinavia should be seen against an American context, and in how the view of the religion there was characterised by an investment in the ideal of religious freedom. This contributed towards anti-Mormonism in the United States being couched in political-moral terms rather than religious ones, and the promotion of robust countermeasures being rooted in an alleged political danger to the American republic. A question here is to what extent this influenced how Mormons were represented in Scandinavia.

A ban on Jesuits (monks ordained in the Catholic order of the Society of Jesus) was also written into the Norwegian Constitution in 1814, and the reasoning behind it had clear points of contact with the prohibition of Jews. The Jesuits were referred to as a state within the state throughout the 18th century, with a lack of loyalty towards secular authorities to the benefit of a supranational papacy. They, too, were alleged to have designs on theocracy. While the Norwegian prohibition of Jews was abolished in 1851, the Jesuit ban would remain in force until 1956. In Denmark and Sweden, however, Jesuits established themselves in the 1870s and 1880s respectively. The long contours in the representation of the Jesuits' political threat will be outlined here, but engaging with representations of this group when the constitutional ban was addressed in the Norwegian parliament in 1897, in 1925 and in 1956 will be of particular importance.

The Norwegian debate on the Jesuits ought to be examined up against similar debates outside the country, especially in Sweden. In the 1920s, the "Catholic danger" became an important public issue in Sweden, and within ecclesiastical circles this was also elevated to a Scandinavian arena. ${ }^{38}$ In the same decade, an attempt to lift the ban in the Norwegian Constitution failed. This renders it natural to investigate whether these debates influenced each other or bore similar features. The last major anti-Catholic discussions in the Swedish Riksdag took place as late as 1961, five years after the repeal of the Jesuit clause in Norway, during the debate on whether Belgian Carmelite nuns ought to be allowed to establish a convent in the country.

Although these notions of Jews, Mormons, and Jesuits belonged to a transnational mindset, and were expressions of stereotypes that flowed freely across borders, the application of them was clearly also an expression of religious nationalism in which religious affiliation constituted a significant factor in the for-

38 Yvonne Maria See Werner, “'The Catholic Danger’: The Changing Patterns of Swedish AntiCatholicism - 1850-1965," in European Anti-Catholicism in a Comparative and Transnational Perspective, ed. Yvonne M. Werner and Jonas Harvard, J. European Studies no. 31 (Amsterdam-New York: Rodopi, 2013), $135 \mathrm{ff}$. 
mation of national identity. ${ }^{39}$ One of this book's points of departure is an understanding that borderland mechanisms are pivotal for group identity by defining the boundaries between exclusion and inclusion. The idea that collective identity is not so much defined by the characteristics of what a group contains (such as culture) as it is by self-perceived boundaries was developed by the Norwegian social anthropologist Fredrik Barth several decades ago. ${ }^{40}$ Barth discussed the importance of boundary-making and boundary maintenance as mechanisms that define ethnic groups. In his seminal work, symbols were instrumental in demarcating differences between groups. The concept has also been applied to nations, and to the construction and maintenance of national identity by stressing the boundaries, and the differences that they make evident. An early example is the US political scientist John Armstrong who, with reference to Barth, emphasised comparison with strangers and exclusion as key elements in group definition and in defining the nation. ${ }^{41}$ Another more recent example is Chris Lorenz, who emphasises the relational character of collective identity and the phenomenon of identity construction by negation. In-groups are consequently defined in relation to out-groups, he argues, and representations of others identify "a difference that makes difference." ${ }^{42}$ Inclusion in a collective, such as a nation, re-

39 See Svein Ivar Angell, Frå splid til nasjonal integrasjon: Norsk nasjonalisme i mellomkrigstida. Kult skriftserie no. 29/Nasjonal identitet no. 4 (Oslo: Norges forskningsråd, 1994) for a discussion on religious nationalism in Norway. See also Philip W. Barker, If God Be For Us: Religious Nationalism in Modern Europe (PhD diss., University of Colorado, 2005), $21 \mathrm{ff}$ for a discussion of concepts.

40 Fredrik Barth, "Introduction,” in Ethnic Groups and Boundaries: The Social Organization of Culture Difference, ed. Fredrik Barth (Bergen-Oslo: Universitetsforlaget, 1969), $15 \mathrm{ff}$. Particularly on the basis of the American psychologist Gordon Allport's classic analysis from 1954, an extensive field of social psychological research has developed that has studied similar relationships between different groups in society more generally, and how inner affiliation and identity develop with or without the use of "scapegoat groups" as common external and contrasting enemies. This is often referred to as "ingroup love, outgroup hate." See Gordon W. Allport, The Nature of Prejudice (Reading, MA: Addison-Wesley Pub. Co., 1979 [1954]), where, among other things, he discussed how Jews were given a "scapegoating” role. For a discussion of Allport's legacy, see the anthology On the Nature of Prejudice: Fifty Years After Allport, eds. John F. Dovidio, Peter Glick and Lurie Rudman (Malden, Mass.: Blackwell Publishing, 2005).

41 John Armstrong, Nations Before Nationalism (Chapel Hill: University of North Carolina Press, 1982), 5.

42 Chris Lorenz, "Representations of Identity: Ethnicity, Race, Class, Gender and Religion: An Introduction to Conceptual History," in The Contested Nation: Ethnicity, Class, Religion and Gender in National Histories, ed. Stefan Berger and Chris Lorenz (Basingstroke: Palgrave MacMillan, 2008), 31. 
quires concurrent exclusion, Lorenz explains. ${ }^{43}$ Stuart Hall has connected this explicitly to representational practices typically understood as "stereotyping," arguing that "difference" is essential to meaning and that the latter could not exist without the former. ${ }^{44}$

Jews, Mormons, and Jesuits were portrayed to the Scandinavian societies as foreign, and all three minorities also had roots outside of these countries. They were also commonly depicted as representatives of foreign, cosmopolitan powers and thus as unpatriotic entities alien to the nation. Consequently, opposition to them was an expression of exclusion on nationalistic grounds. As excluded "Others," they enabled inclusion for members of the nation's in-group, and as stereotyped symbols of otherness, they constituted important instruments in the making and maintenance of the nation's boundaries.

The discourse that justified the need for national preservation bore transnational traits. In this manner, transnational conceptions contributed towards defining national identity. At the same time, they helped to define what it meant to be a good citizen of the nation by identifying and defining a form of anti-citizen - in contrast to a good citizen. This was important in a period - from the end of the 18th century onwards - when new understandings of the concepts of nation and citizen were being thematised in Europe and as new national communities were being defined and consolidated throughout the 19th and 20th centuries. In this way, Jews, Mormons, and Jesuits all played important nation-building roles by virtue of their outsiderness.

In showing how these religious minorities were perceived in Scandinavia from the end of the 18th century onwards, important historical aspects of the perception of religious otherness in the Scandinavian countries will also be thematised. Common to all the groups was that their existence in all the countries was perceived as a danger to society - with societal upheaval as a potential outcome. Despite the stark warnings and allegations of the serious consequences of allowing and tolerating these minorities, another commonality is that they did not, in the end, provoke social upheaval or pose significant challenges to the state.

On the contrary, Jews and Mormons formed religious communities that were in many ways integrated into an increasingly pluralistic religious society, and the "Jesuit danger" has been absent as a trope in Scandinavian public debate since the 1950s. The representation of the threat posed to society by these groups thus

43 Lorenz, "Representations of Identity," 25.

44 Stuart Hall, "The Spectacle of the 'Other'," in Representation: Cultural Representaions and Signifying Practices, ed. Stuart Hall (London-Thousand Oaks-New Dehli: Sage Publication, 1997), 225, $234 \mathrm{f}$. 
appears to be a moral panic set in motion by an anxious majority society's brush with religious heterodoxy. For this reason the theme of this book is not only of historical relevance, but also of timeliness in a contemporary debate on religious otherness and in the discourse on the threat to society presented by religious pluralism. 